\title{
Microphysics parameterization sensitivity of the WRF Model version 3.1.7 to extreme precipitation: evaluation of the 1997 New Year's flood of California
}

\author{
Elcin Tan
}

5 Department of Meteorological Engineering, Istanbul Technical University, Istanbul, 34469, Turkey Correspondence to: Elcin Tan (elcin.tan@itu.edu.tr)

\begin{abstract}
Providing high accuracy in quantitative extreme precipitation forecasting (QEPF) is still a challenge. California is vulnerable to extreme precipitation, which occurs due to atmospheric rivers and might be more intense with climate change. Accordingly, this study is an attempt to evaluate the extreme precipitation forecasting performance of a QPF model, the Weather Research and Forecast Model, version 3.1.7, for the extreme precipitation event that caused the 1997 New Year's flood in California. Sensitivities of 19 microphysics schemes are tested by utilizing 18 various Goodness of Fit (GoF) tests for hourly and point-wise comparisons between 3-km horizontal domain resolution simulations of the WRF Model and observations. The results indicate that the coefficient of persistence

15 (cp) is the first metric that needs to be evaluated because it determines whether simulation versus observation values are reasonable. Comparisons of 3 out of 8 stations in the American River Watershed passed this test. The results also show that Normalized Root Mean Square Errors (NRMSE) and Percent Bias (PBIAS) metrics are more representative than others due to their ability to discriminate model performances. Further, microphysics (MP) schemes are also significantly sensitive to location.

20 Although 3 of the stations that passed the cp test are quite near to each other spatially, different MP schemes become prominent for different observation locations. For instance, for the ALP station, MP3, MP8, MP17, and MP28 indicate better performances, whereas the errors of MP3, MP8, MP9, and MP17 are less than other MPs for the BTA station. However, MP11 has the only reasonable results, according to $\mathrm{cp}$ values for the CAP station. The MPs are also evaluated for 72-hr and basin-averaged 25 precipitation estimations of the WRF Model by means of true percent relative errors. The results show that the accuracy of the WRF Model is much higher for the 72-hr total basin-averaged evaluations than
\end{abstract}


Geosci. Model Dev. Discuss., doi:10.5194/gmd-2016-94, 2016

Manuscript under review for journal Geosci. Model Dev.

Published: 21 June 2016

(c) Author(s) 2016. CC-BY 3.0 License.

for the hourly and point-wise comparisons. Thus, the Thompson Scheme (MP8) indicates more trustworthy results than others, with a $3.1 \%$ true percent relative error. Although WRF simulations overestimate the 72-hr basin-averaged precipitation for most of the MP schemes, this may not be pronounced for moderate, heavy, and extreme precipitation when hourly and point-wise evaluations are

5 performed but is valid for light precipitation.

\section{Introduction}

The IPCC noted that the magnitude, frequency, and duration of extreme events may increase as a result of climate change (2012). This impact could be significant for regions such as California where drought intensities also tend to increase and excessive amounts of precipitation should therefore be saved for

10 future periods of drought. When drought causes these regions to take one step back, extreme precipitation events can take them two steps forward. Hence, smart and new water management strategies should be developed to advance climate change adaptation. Some of the solutions might be related to improving the time and space problem of quantitative extreme precipitation forecasting (QEPF). The Weather Research and Forecasting Model (WRF) (Skamarock et al., 2008) has been

15 widely used to increase resilience to extreme precipitation events in California (Jankov et al., 2007; Jankov et al., 2009; Tan, 2010; Eiserloh and Chiao, 2014), which are closely correlated with atmospheric river events (Tan, 2010). Atmospheric rivers are also expected to increase in terms of both frequency and intensity with climate change (Dettinger, 2011). Generally, for precipitation simulations, a combination of the microphysical, cumulus parameterization and the planetary boundary layer 20 parameterization schemes is mainly evaluated using the WRF Model, although all of the parameterization schemes and processes have effects on precipitation occurrence. Moreover, microphysical schemes play a significant role if the horizontal resolution of the interested domain is finer than $9 \mathrm{~km}$. Recent studies have been conducted for the evaluation of the microphysics schemes of the WRF Model with respect to winter precipitation in California, with a focus on atmospheric river

25 phenomena (Jankov et al., 2007; Jankov et al., 2009; Tan, 2010; Jankov et al., 2011; Han et al., 2013), which is the reason for the extreme precipitation that occurs along the West coast of the US (Zhu and Newell, 1998; Ralph et al., 2004; Tan, 2010; Houze, 2012). Jankov et al. (2007) evaluated the Lin, 
Geosci. Model Dev. Discuss., doi:10.5194/gmd-2016-94, 2016

Manuscript under review for journal Geosci. Model Dev.

Published: 21 June 2016

(c) Author(s) 2016. CC-BY 3.0 License.

Ferrier, WSM6, and Thompson schemes of version 2 of the WRF-ARW for the February 27, 2006, atmospheric river event by using a 3-km horizontal grid resolution. Jankov et al. (2009) also investigated the Lin, WRF Single-Moment 6-Class (WSM6), Thompson, and Schultz microphysics schemes for a 3-km horizontal resolution by simulating December 30-31, 2005, January 1, 2006,

5 February 1, 2006, February 27, 2006, and March 5, 2006 events. Jankov et al. (2011) included the double-moment Morrison microphysics scheme in the four MP physics they used in their previous research (Jankov et al., 2009) and changed the finest horizontal grid resolution to $4 \mathrm{~km}$ to evaluate only the December 30-31, 2005 event, using version 3.0 of the WRF Model. Han et al. (2013) evaluated the Goddard scheme, WRF single-moment 6-class scheme, Thompson scheme and Morrison double-

10 moment scheme of version 3.1 of the WRF Model by simulating the December 30-31, 2005 atmospheric river (AR) event that occurred in northern California and Nevada, with a 1.3-km horizontal resolution. Tan (2010) calibrated the WRF Model version 3.1.1 by using the Kessler, Lin, WSM 3class, WSM 5-class, Ferrier, WSM 6-class, Goddard GCE, Thompson, Morrison, WDM 5-class, WDM 6-class, and Old Thompson schemes for the 1997 New Year's event at the American River Watershed,

15 with a 3-km horizontal resolution and 72-hr basin-averaged consideration for the purpose of probable maximum precipitation (PMP) estimation. She also validated the WRF Model using the Thompson microphysics scheme for 42 historical atmospheric river events that occurred between 1951 and 2002.

Hereupon, the main goal of this study is to evaluate hourly quantitative extreme precipitation forecasting (QEPF) performance of the WRF Model for the most extreme atmospheric river event in the 20 history of California. The 1997 New Year's flood, which occurred between December 26, 1996, and January 3, 1997, has been ranked as the fifth of California's top 15 weather events in the 1900s (URL1) and is still the major impactful atmospheric river event of the state. Thus, the 1997 New Year's atmospheric river event is simulated for the evaluation of version 3.7.1 of the WRF Model. In this way, new MP schemes that were not evaluated by Tan (2010) are also included in this study. As a result, 25 hourly QPF of the total 19 bulk parameterization schemes is evaluated by using 18 different Goodness of Fit $(\mathrm{GoF})$ tests at a 3-km horizontal grid resolution by comparing hourly ground-based rain gauge observations. Additionally, 72-hr basin-averaged values are also discussed for comparison with the previous studies. 
Geosci. Model Dev. Discuss., doi:10.5194/gmd-2016-94, 2016

Manuscript under review for journal Geosci. Model Dev.

Published: 21 June 2016

(c) Author(s) 2016. CC-BY 3.0 License.

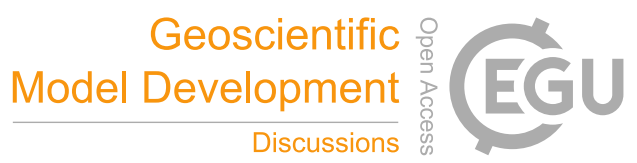

This study is organized as follows: Section 2 presents data used for the simulations and comparisons. The model design is detailed in Section 3, including MP schemes and evaluation methods. Section 4 discusses results in terms of both in-situ observations and 72-hr basin-averaged values. Finally, the study is concluded in Section 5 .

5

\section{Data}

\subsection{Reanalysis Data Set}

WRF simulations are initialized by using a 6-hourly NCEP/NCAR Global Reanalysis Model (Kalnay et al., 1996). The resolution of this model is T62 $(209 \mathrm{~km})$ with 28 vertical sigma levels. The dataset

$10\left(2.5^{\circ} \times 2.5^{\circ}\right)$ is continuously available online, starting from 1948, at the Research Data Archive (RDA) of the University Corporation for Atmospheric Research (UCAR) (NCEP et al., 1994).

\subsection{Observational Data}

Hourly rain-gauge data are obtained from the California Data Exchange Center (CDEC) (URL-2) for the American River Watershed where Pacific Standard Time (PST) is utilized as the local time. Because 15 the WRF Model uses Coordinated Universal Time (UTC), all the comparisons are scaled accordingly. That is, the WRF Model comparisons are presented in this study based on UTC and 72-hr basinaveraged comparisons are kept with local time comparisons in order to be consistent with the literature. Hourly rainfall rates of the WRF model are evaluated by considering 8 rain gauge stations: Alpha (ALP- 2316 m), Beta (BTA- 2316 m), Owens Camp (OWC- 1371 m), Caples Lake (CAP- 2438 m), 20 Hell Hole (HLH- 1396 m), Pilot Hill (PIH- 366 m), Lincoln (LCN- 61 m), and Hurley (HUR- 11 m) (Figure 1). The stations' IDs and their elevations are given in the parentheses.

Precipitation rates are classified as follows: Light: Trace- $2.5 \mathrm{~mm} / \mathrm{hr}$, Moderate: $2.5 \mathrm{~mm} / \mathrm{hr}-7.5 \mathrm{~mm} / \mathrm{hr}$, Heavy: $7.5 \mathrm{~mm} / \mathrm{hr}-10 \mathrm{~mm} / \mathrm{hr}$, and Extreme: $>10 \mathrm{~mm} / \mathrm{hr}$.

The hourly time series of each station shows that the ALP and BTA stations observed extreme 25 precipitation during the New Year's flood of 1997 (Figure 2). 
Geosci. Model Dev. Discuss., doi:10.5194/gmd-2016-94, 2016

Manuscript under review for journal Geosci. Model Dev.

Published: 21 June 2016

(c) Author(s) 2016. CC-BY 3.0 License.

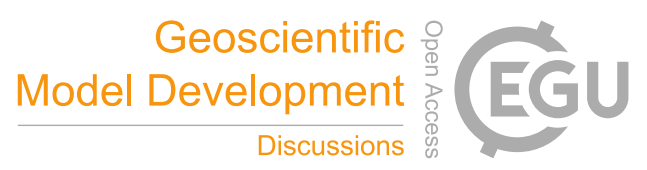

(c) (i)

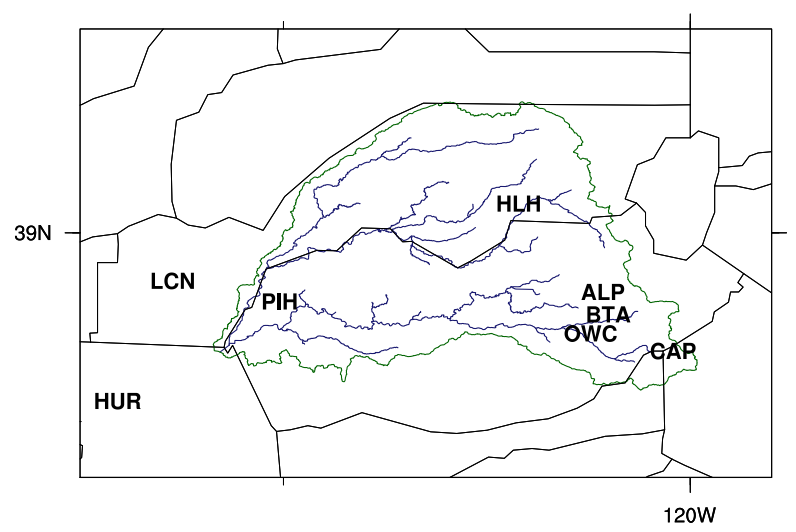

Figure 1: The map of the American River Watershed and the precipitation stations

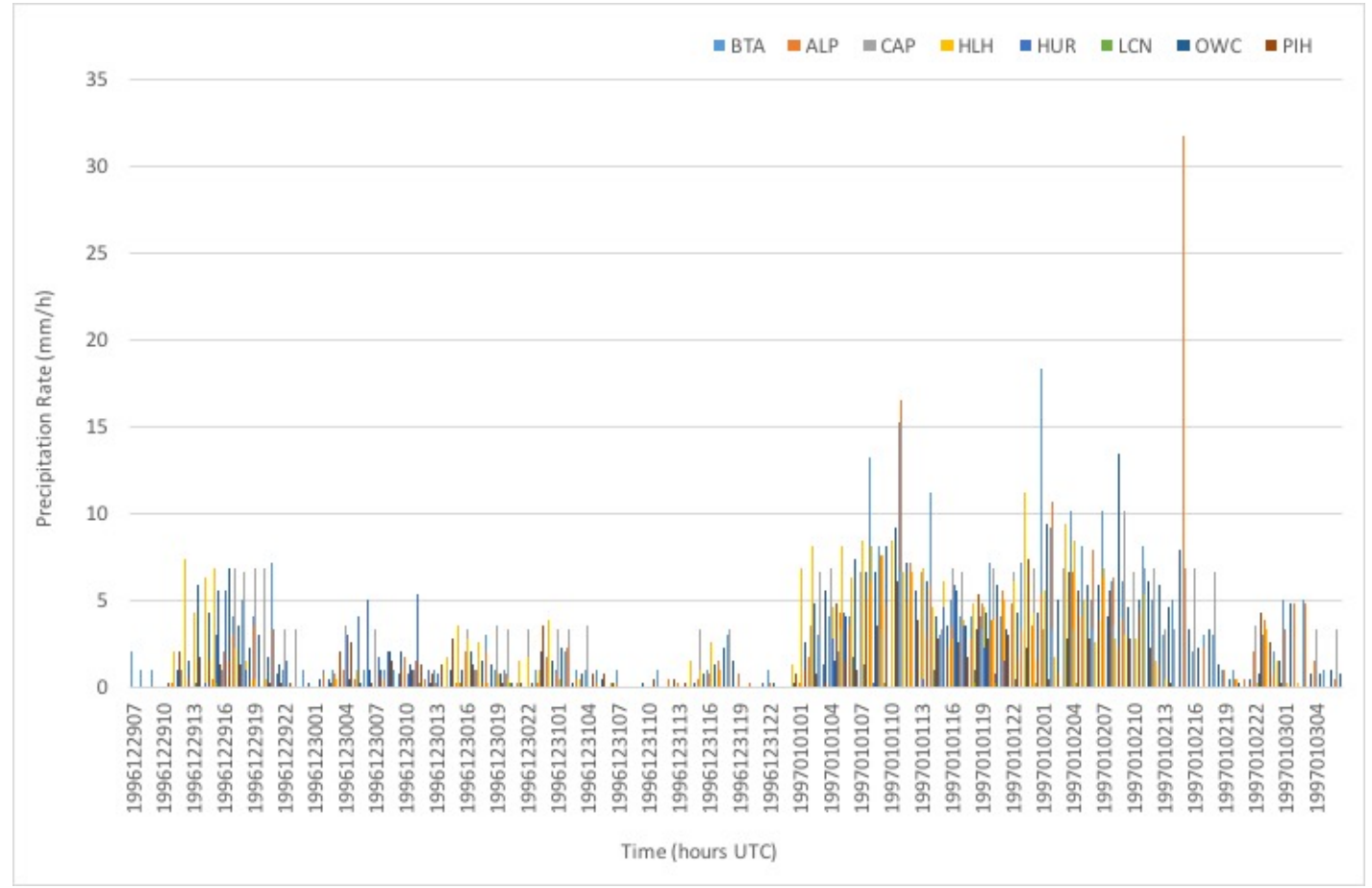

5

Figure 2: Precipitation rate hourly time series of 8 rain gauge stations. 
Geosci. Model Dev. Discuss., doi:10.5194/gmd-2016-94, 2016

Manuscript under review for journal Geosci. Model Dev.

Published: 21 June 2016

(c) Author(s) 2016. CC-BY 3.0 License.

These rain gauges are not included in the estimation of the 72-hr basin averaged precipitation values. The 72-hr basin-averaged precipitation data obtained by USACE (2005) is used to compare with the precipitation output of the WRF Model. The 72-hr basin-averaged output of the WRF Model is 5 calculated by using the shape file masking method of the NCAR Command Language (NCL, 2016).

\section{Model design}

Version 3.7.1 of the Weather Research and Forecast Model (Skamarock et al., 2008) is utilized in this study, and the 72-hr basin-averaged results are compared to the results of Tan (2010), who used 10 versions 3.1 and 3.1 .1 of the same model. The model design exactly follows that of Tan (2010) so that microphysics parameterization sensitivities can be discussed. The domain configuration is presented in Figure 3, where the outer-most domain (D1) has a 27-km resolution and its two-way nested domains are configured with a ratio of 3 so that the horizontal resolution of the finest domain (D3) is $3 \mathrm{~km}$.

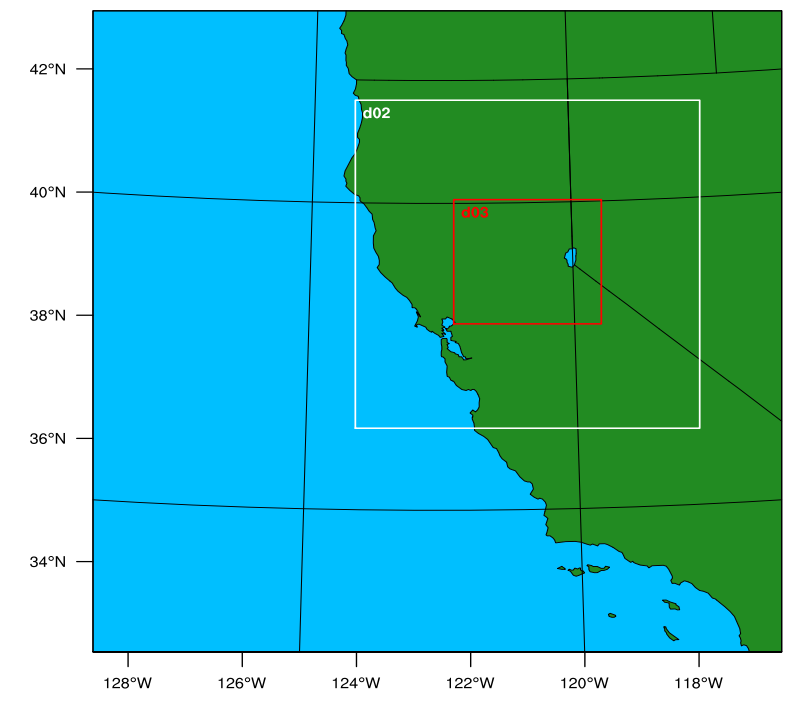

Figure 3: The WRF-ARW model domain configuration 
Geosci. Model Dev. Discuss., doi:10.5194/gmd-2016-94, 2016

Manuscript under review for journal Geosci. Model Dev.

Published: 21 June 2016

(c) Author(s) 2016. CC-BY 3.0 License.

The American River Watershed is centered on the finest resolution $(3 \mathrm{~km})$ domain. D1 consists of $43 \mathrm{x}$ $44 \times 28$ grid points, the middle domain (D2) has $64 \times 67 \times 28$ grid points, and D3 has $82 \times 76 \times 28$ grid points for the meridional, zonal, and vertical directions, respectively. Lambert conformal is used for

5 map projection. The cumulus parameterization scheme, 3D Grell, is only utilized for 27- and 9-km domains, while cloud microphysics schemes are switched on only for 9- and 3-km domains, as suggested by Tan (2010). Because several studies indicate that the YSU planetary boundary layer (PBL) scheme has less bias than other PBL schemes, all microphysics sensitivities are tested using this scheme (Hu et al., 2010; Tan, 2010; Gomez-Navarro et al., 2015). Long wave radiation parameterization is

10 selected as the rrtm scheme, whereas for shortwave radiation the Dudhia scheme is used. The Unified Noah model is utilized as the land-surface parameterization without using any urban canopy model. The revised MM5 Monin-Obukhov scheme is applied as a surface layer option. The simulations began at 6 am, December 29, 1996 and stopped at 6 am, January 3, 1997.

\subsection{MP schemes}

15 WRF-ARW Model version 3.7.1 has 23 microphysics (MP) options. Four of these options are not included in this study for the following reasons. One of those four options is option zero (mp_physics=0), which means that no microphysics is used. Another one is the NSSL 2-moment 4-ice scheme (Mansell et al, 2010) with predicted CCN (mp_physics=18), which is suggested for use with idealized cases rather than real ones. The remaining two are spectral bin microphysics, i.e., fast (Khain 20 et al, 2010), and full (Khain et al, 2004) versions of HUJI (Hebrew University of Jerusalem, Israel), i.e., $\mathrm{mp} \_$physics $=30$ and mp_physics $=32$, respectively, which are beyond the scope of this study. Therefore, 19 bulk microphysical parameterization schemes are evaluated with respect to rainfall amount. A brief summary of these 19 schemes is presented in Table 1, where the first column is the Scheme ID number that the WRF name list uses. The second column of the table provides the names of the schemes and the third one indicates the number of the variables predicted by these schemes, such as water vapor, rain, snow, cloud ice, cloud water, graupel, hail, and aerosol. The fourth and the fifth columns indicate whether ice-phase and mixed phase processes are utilized, respectively. 
Geosci. Model Dev. Discuss., doi:10.5194/gmd-2016-94, 2016

Manuscript under review for journal Geosci. Model Dev.

Published: 21 June 2016

(c) Author(s) 2016. CC-BY 3.0 License.

Table 1. General properties of the tested microphysics schemes.

\begin{tabular}{|c|c|c|c|c|}
\hline Scheme ID & Scheme Name & Number of Variables & Ice-Phase Processes & Mixed Phase Processes \\
\hline MP1 & Kessler & 3 & No & No \\
\hline MP2 & Lin et al. & 6 & Yes & Yes \\
\hline MP3 & WSM 3-class simple ice & 3 & Yes & No \\
\hline MP4 & WSM 5-class & 5 & Yes & Yes \\
\hline MP5 & Ferrier (New Eta) & 4 & Yes & Yes \\
\hline MP6 & WSM 6-class & 6 & Yes & Yes \\
\hline MP7 & Goddard GCE & 6 & Yes & Yes \\
\hline MP8 & Thompson & 5 & Yes & Yes \\
\hline MP9 & Milbrandt-Yau & 7 & Yes & Yes \\
\hline MP10 & Morrison & 6 & Yes & Yes \\
\hline MP11 & CAM 5.1 & 4 & Yes & No \\
\hline MP13 & SBU_YLIN & 5 & Yes & Yes \\
\hline MP14 & WDM 5-class & 5 & Yes & Yes \\
\hline MP16 & WDM 6-class & 6 & Yes & Yes \\
\hline MP17 & NSSL 2-moment & 6 & Yes & Yes \\
\hline MP19 & NSSL 1-moment & 7 & Yes & Yes \\
\hline MP21 & NSSL 1-moment & 6 & Yes & Yes \\
\hline MP28 & Aerosol-aware Thompson & 8 & Yes & Yes \\
\hline MP95 & Ferrier (Old Eta) & 2 & No & No \\
\hline
\end{tabular}

Although each scheme has been constructed by using a couple of previous parameterization methods, they might be classified into 4 groups in terms of their main origins:

5 1. Kessler type- MP1: Kessler Scheme (Kessler, 1995);

2. Rutledge and Hobbs (1984; RH84) type- MP2: Lin et al. Scheme (1983), MP3: WRF Single-moment 3-class Scheme (Hong et al., 2004), MP4: WRF Single-moment 5-class Scheme (Hong et al, 2004), MP6: WRF Single-moment 6-class Scheme (Hong and Lim, 2006), MP9: Milbrandt-Yau Double Moment Scheme (Milbrandt and Yau, 2005a; Milbrandt and Yau, 2005b), MP10: Morrison 2-moment

10 Scheme (Morrison et al, 2009), MP11: CAM V5.1 2-moment 5-class Scheme (Eaton, 2011), MP13: Stony-Brook University Scheme (Lin and Colle, 2011), MP14: WRF Double Moment 5-class Scheme 
Geosci. Model Dev. Discuss., doi:10.5194/gmd-2016-94, 2016

Manuscript under review for journal Geosci. Model Dev.

Published: 21 June 2016

(c) Author(s) 2016. CC-BY 3.0 License.

(Lim and Hong, 2010), MP16: WRF Double Moment 6-class Schemes (Lim and Hong, 2010), and MP95: Ferrier (Old Eta) (Ferrier et al., 1995);

3. Reisner et al. (1998; RRB98) type- MP5: Ferrier (New Eta) Scheme (NOAA, 2001), MP7: Goddard Scheme (Tao et al., 1989), MP8: Thompson Scheme (Thompson et al, 2008), and MP28: Aerosol-

5 Aware Thompson Scheme (Gilmore et al., 2014);

4. Ziegler (1985) type- MP17: NSSL 2-moment Scheme (Mansell et al., 2010), MP19: NSSL 1moment 7-class Scheme, and MP21: NSSL 1-moment 6-class Scheme (Gilmore et al., 2004).

\subsection{Goodness of fit (GoF) tests}

10 The 1997 New Year's flood event is simulated to compare the sensitivities of the WRF Model to the extreme precipitation that occurred due to atmospheric rivers. Because the 1997 flood is the highest ranked atmospheric river event, considering the loss of life and property, this event is selected as the case. Precipitation simulations of 19 microphysics schemes of the WRF Model version 3.7.1 are compared to the hourly rain gauge observations. First, time series of the observed and modeled values

15 are plotted for the 8 rain-gauge locations. Precipitation rates of the model at these locations are estimated by using the bilinear interpolation method following Tan (2010) rather than using the nearest grid point value.

Chai and Draxler (2014) suggested that a combination of metrics should be used to assess model performance rather than utilizing only Root Mean Square Error (RMSE) and Mean Absolute Error

20 (MAE). Therefore, 18 Goodness of Fit (GoF) tests of the hydroGOF-package in R (Mauricio, 2014) are calculated to compare simulated and observed rainfall rate time series. The GoF tests, utilized in this study, are Mean Error (ME), Mean Absolute Error (MAE), Mean Squared Error (MSE), Root Mean Square Error (RMSE), Normalized Root Mean Square Error (NRMSE), Percent Bias (PBIAS), Ratio of RMSE to the standard deviation of the observations (RSR), Ratio of Standard Deviations (rSD), Nash-

25 Sutcliffe Efficiency (NSE), Modified Nash-Sutcliffe Efficiency (mNSE), Index of Agreement (d), Modified Index of Agreement (md), Coefficient of Persistence (cp), Pearson product-moment 
Geosci. Model Dev. Discuss., doi:10.5194/gmd-2016-94, 2016

Manuscript under review for journal Geosci. Model Dev.

Published: 21 June 2016

(c) Author(s) 2016. CC-BY 3.0 License.

correlation coefficient (r), Coefficient of determination (R2), Coefficient of determination multiplied by the slope of the regression line (bR2), Kling-Gupta efficiency (KGE), and Volumetric Efficiency (VE). In addition to the hourly precipitation assessment of the model parameterizations, 72-hour basinaveraged precipitation values of the American River Watershed of California are estimated by using the

5 shape file masking method of NCL (NCL, 2016). The total precipitation values that are masked out by this method are then compared to the basin-averaged observation value obtained by USACE (2005). The 72-hr basin-averaged results of each microphysics option are also evaluated by estimating the true percent relative error.

\section{Results}

$10 \quad 4.1$ Hourly and rain gauge-based comparisons

As mentioned in Section 3.3, $18 \mathrm{GoF}$ methods are utilized to evaluate the performance of the microphysics schemes based on hourly precipitation simulations at selected rain gauge stations. One of those tests, i.e., coefficient of persistence ( $\mathrm{cp}$ ), indicates that the model performance can be acceptable if its value is either greater than or equal to zero. The cp values of model and observation comparisons at 155 out of the 8 rain-gauge station locations, i.e., HLH, HUR, LCN, OWC, and PIH (Figure 1), are less than zero for all of the MP options. Thus, the model performance is not acceptable for them in terms of hourly precipitation comparisons. For this reason, time series graphics and GoF test results for these unacceptable station locations are not given here. This might show us that a significant source of error is still added to the model by means of MP schemes depending on the location with the consideration of

20 hourly rainfall assessments. However, the results of some MP schemes are found acceptable for the observations of the ALP, BTA, and CAP stations, whose graphical comparisons are presented in Figure 4, Figure 5, and Figure 6, respectively, including their GoF test results (Figure 7, Figure 8, and Figure 9). After accepting the performances of MP schemes based on cp values, the best MP scheme is determined by considering all of the GoF metrics studied. In general, the results show that the metrics capability in discriminating model performances is of great importance, as Chai and Draxler (2014) mentioned. According to the hourly extreme precipitation simulations, the PBIAS metrics can be 
Geosci. Model Dev. Discuss., doi:10.5194/gmd-2016-94, 2016

Manuscript under review for journal Geosci. Model Dev.

Published: 21 June 2016

(c) Author(s) 2016. CC-BY 3.0 License.

evaluated as the best GoF test in terms of discriminating the errors (Figure $7 \mathrm{~b}$, Figure $8 \mathrm{~b}$, and Figure 9b). However, MSE is also a good metric because it exaggerates the worst performances. Although Chai and Draxler (2014) indicate that RMSE is better than MAE, for extreme precipitation evaluations, they both have the similar error patterns for all MPs. Moreover, ME and NRMSE indicate a similarity 5 between MAE and RMSE, as expected. The rest of the GoF tests, i.e., d, md, r, R2, bR2, RSR, rSD, NSE, mNSE, KGE, and VE, may not be used to evaluate the best options alone. For this reason, a combination of NRMSE and PBIAS metrics is utilized to determine the best MP option, depending on the station location.

For extreme precipitation evaluation, time series graphics indicate that none of the MP schemes is able

10 to estimate the maximum precipitation amount of $31.75 \mathrm{~mm}$ recorded on January 2, 1997 at 22:00 UTC at the ALP station (Figure 4). Moreover, neither spatial nor temporal shift for this maximum amount is detected in the model output. Although MP11 tends to estimate the maximum, it predicts so much rainfall for the remaining hours that the $\mathrm{cp}$ value of this scheme is less than zero, which means that the results of MP11 are unreasonable for ALP station comparisons. The MP14, MP19, and MP21 options

15 also cannot be included in the comparisons due to a similar reason. The rainfall amounts of the 15 other MP schemes for the ALP station are acceptable (Figure 4 and Figure 7). MP3 and MP8 have minimum PBIAS values, i.e., $4.6 \%$ and $2.9 \%$, respectively, whereas MP17 and MP28 are the best options based on NRMSE values, i.e., $101.5 \%$ and $105.6 \%$, respectively (Figure $7 \mathrm{~b}$ ).

The extreme rainfall amount observed at the BTA station is $18.3 \mathrm{~mm}$, which is also not exactly

20 simulated by any of the MPs, although some of them estimated this amount with a time shift. The GoF test results show different patterns for the BTA station than those of the ALP station. Nine MPs, MP1, MP2, MP4, MP6, MP11, MP14, MP16, MP19, and MP21, could not pass the threshold value of 0 for the cp test (Figure 5 and Figure 8a). It seems that these MPs cannot capture abrupt precipitation changes very well (Figure 5). For BTA station comparisons, MP3 and MP8 have minimum PBIAS values, i.e., -

$251.3 \%$ and $-4.7 \%$, respectively. MP9 and MP17 have better test results than the others in terms of NRMSE metrics, i.e., 97.2\% and 98.3\%, respectively (Figure $8 b$ ).

Although the extreme rainfall observed $(10.2 \mathrm{~mm})$ at the CAP station is less than that at the ALP and BTA stations, precipitation observations indicate an unusual pattern at the CAP station: the rainfall 
Geosci. Model Dev. Discuss., doi:10.5194/gmd-2016-94, 2016

Manuscript under review for journal Geosci. Model Dev.

Published: 21 June 2016

(c) Author(s) 2016. CC-BY 3.0 License.

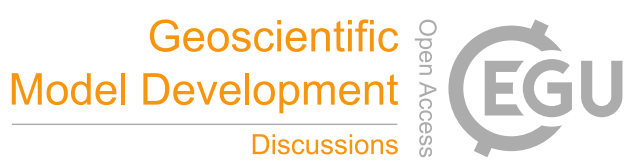

(c) (i)

continues at a moderate rate between $3.5 \mathrm{~mm} / \mathrm{hr}$ and $7 \mathrm{~mm} / \mathrm{hr}$ approximately 36 hours. Simulation results of this stationary rainfall pattern show that only MP11 passes the cp threshold, although it could not pass this level for the ALP and BTA stations. PBIAS and NRMSE values for MP11 are $-8.9 \%$ and $104.9 \%$, respectively (Figure 9b).

5
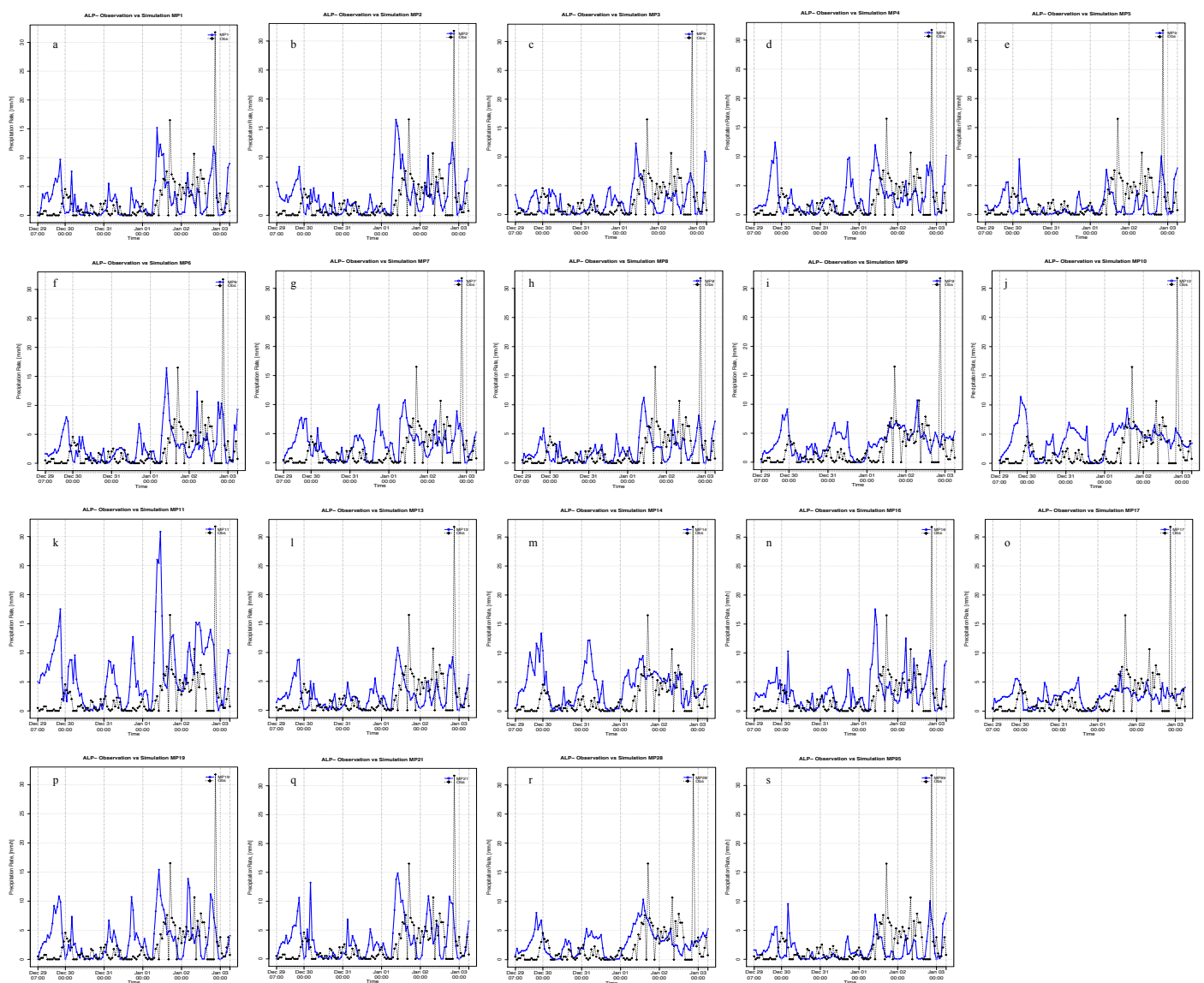

10

Figure 4. Observation versus model comparisons at the ALPHA (ALP) station for each microphysics option in terms of hourly precipitation (a. MP1, b. MP2, c. MP3, d. MP4, e. MP5, f. MP6, g. MP7, h. MP8, i. MP9, j. MP10, k. MP11, l. MP13, m. MP14, n. MP16, o. MP17, p. MP19, q. MP21, r. MP28, s. MP95) 
Geosci. Model Dev. Discuss., doi:10.5194/gmd-2016-94, 2016 Manuscript under review for journal Geosci. Model Dev.

Published: 21 June 2016

(c) Author(s) 2016. CC-BY 3.0 License.
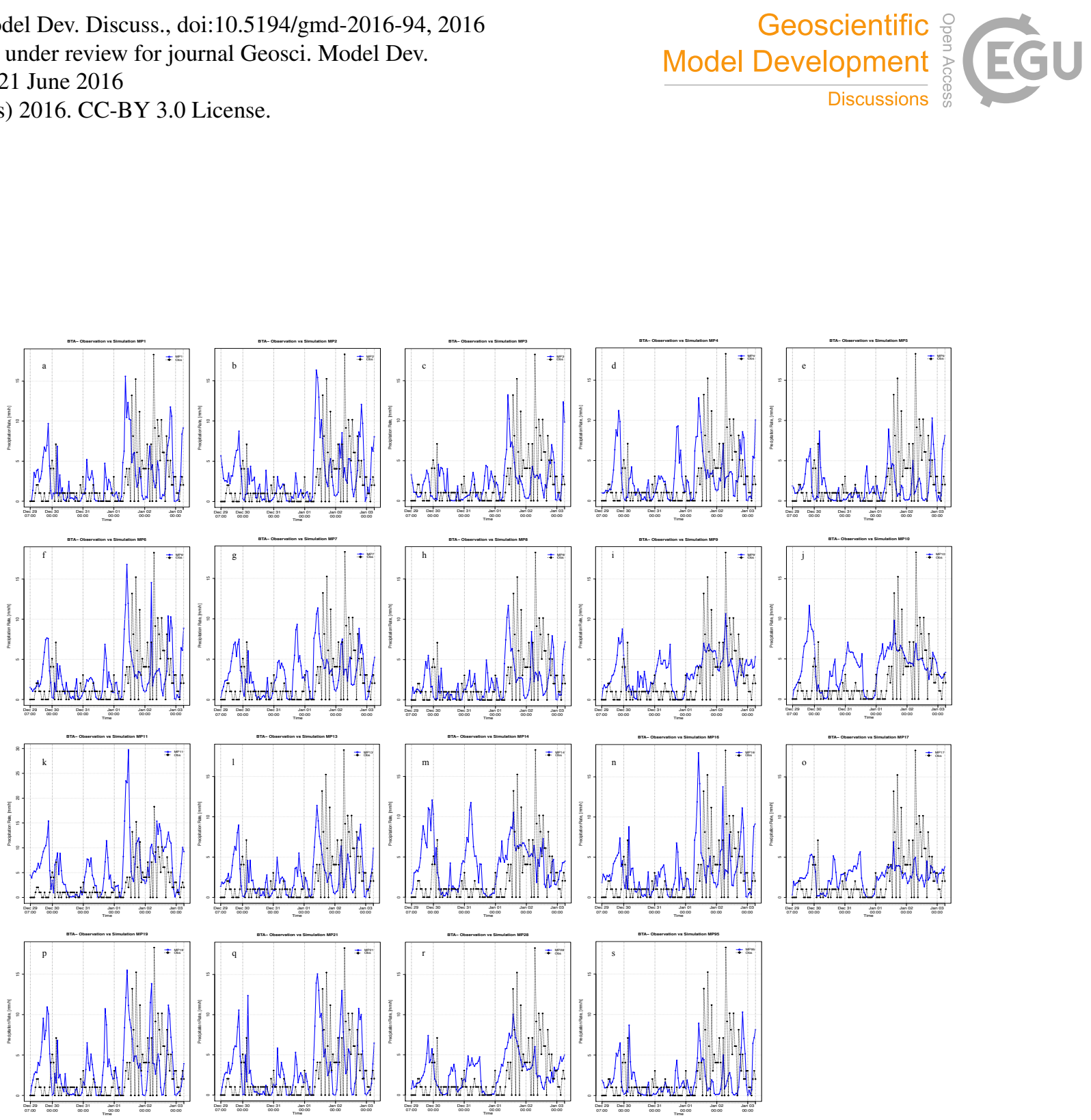

Figure 5. Observation versus model comparisons at the BETA (BTA) station for each microphysics option in terms of hourly precipitation (a. MP1, b. MP2, c. MP3, d. MP4, e. MP5, f. MP6, g. MP7, h. MP8, i. MP9, j. MP10, k. MP11, l. MP13, m. MP14, n.

MP16, o. MP17, p. MP19, q. MP21, r. MP28, s. MP95) 
Geosci. Model Dev. Discuss., doi:10.5194/gmd-2016-94, 2016 Manuscript under review for journal Geosci. Model Dev.

Published: 21 June 2016

(c) Author(s) 2016. CC-BY 3.0 License.
Geoscientific 을 Model Development

Discussions
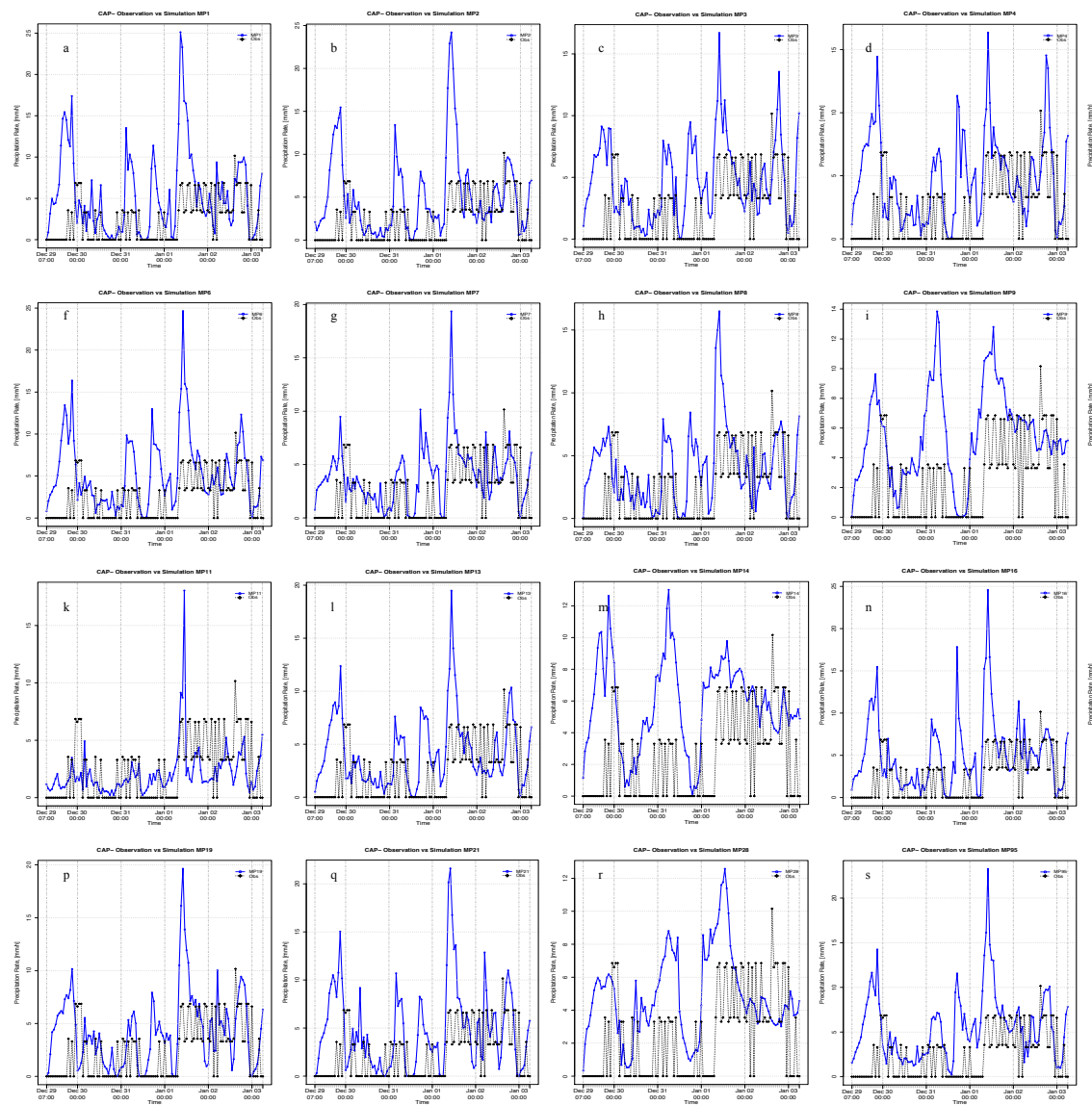
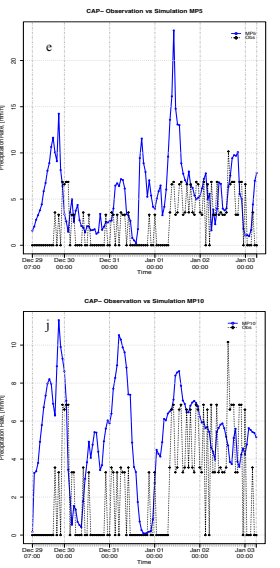

Figure 6. Observation versus model comparisons at the CAPLES LAKE (CAP) station for each microphysics option in terms of hourly precipitation (a. MP1, b. MP2, c. MP3, d. MP4, e. MP5, f. MP6, g. MP7, h. MP8, i. MP9, j. MP10, k. MP11, l. MP13, m. MP14, n. MP16, o. MP17, p. MP19, q. MP21, r. MP28, s. MP95) 
Geosci. Model Dev. Discuss., doi:10.5194/gmd-2016-94, 2016

Manuscript under review for journal Geosci. Model Dev.

Published: 21 June 2016

(c) Author(s) 2016. CC-BY 3.0 License.

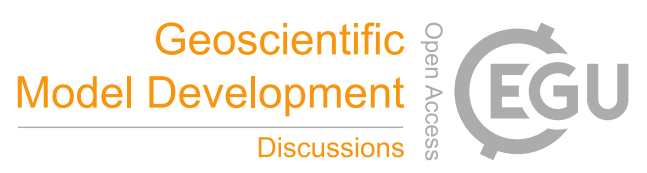

(c) (i)

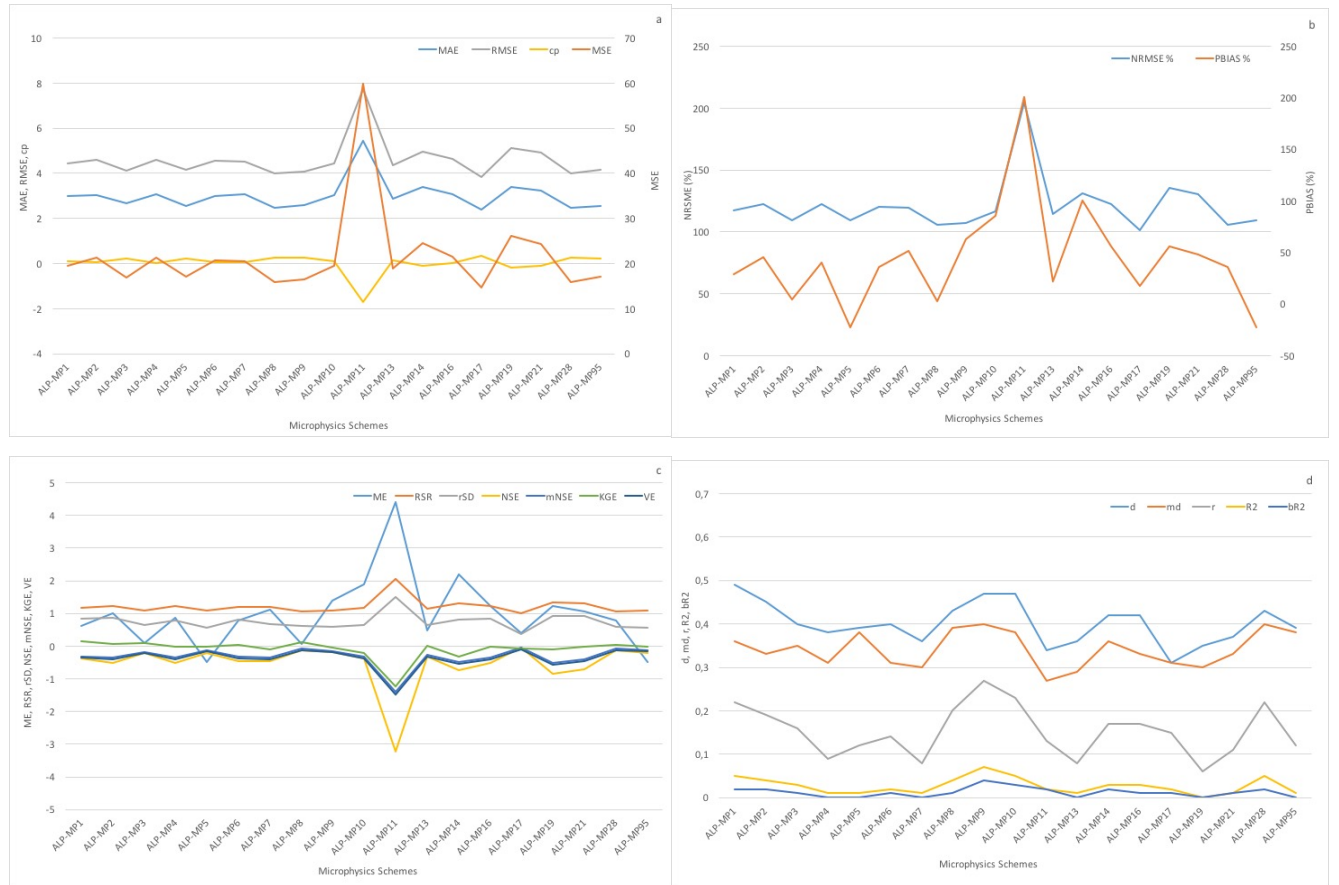

Figure 7. Microphysics Schemes versus errors at the ALPHA (ALP) station for each goodness of fit test class (a. MAE, RMSE, cp, MSE, b. NRMSE, PBIAS, c. ME, RSR, rSD, NSE, mNSE, KGE, VE, d. d, md, r, R2, bR2) 
Geosci. Model Dev. Discuss., doi:10.5194/gmd-2016-94, 2016

Manuscript under review for journal Geosci. Model Dev.

Published: 21 June 2016

(c) Author(s) 2016. CC-BY 3.0 License.

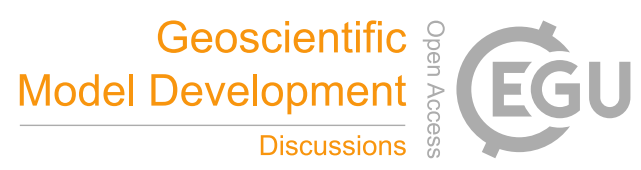

(c) (1)

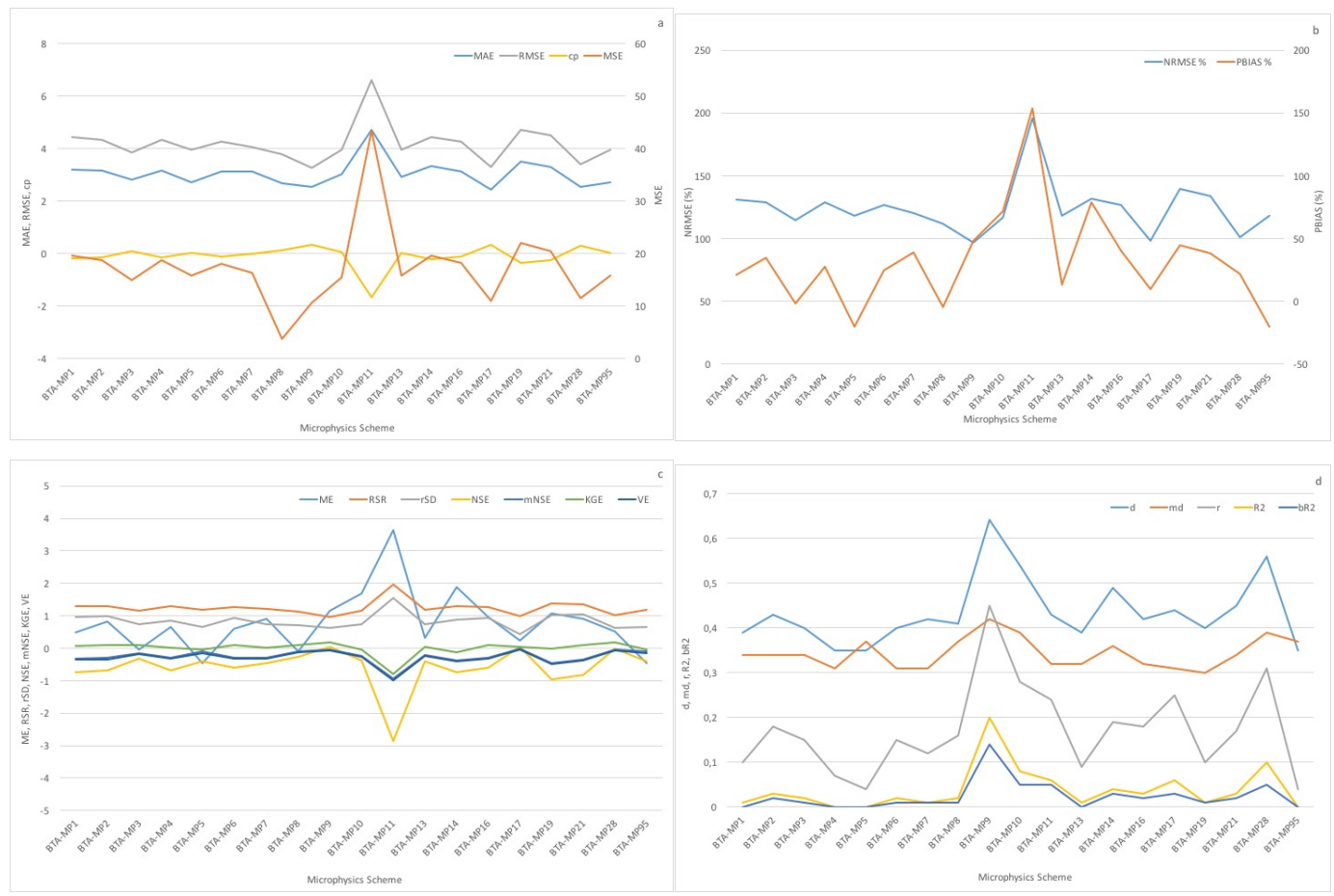

Figure 8. Microphysics Schemes versus errors at the BETA (BTA) station for each goodnees of fit test class (a. MAE, RMSE, cp, MSE, b. NRMSE, PBIAS, c. ME, RSR, rSD, NSE, mNSE, KGE, VE, d. d, md, r, R2, bR2) 
Geosci. Model Dev. Discuss., doi:10.5194/gmd-2016-94, 2016

Manuscript under review for journal Geosci. Model Dev.

Published: 21 June 2016

(c) Author(s) 2016. CC-BY 3.0 License.

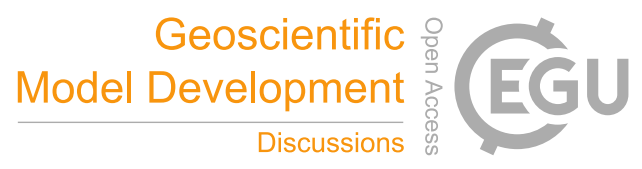

(c) (1)

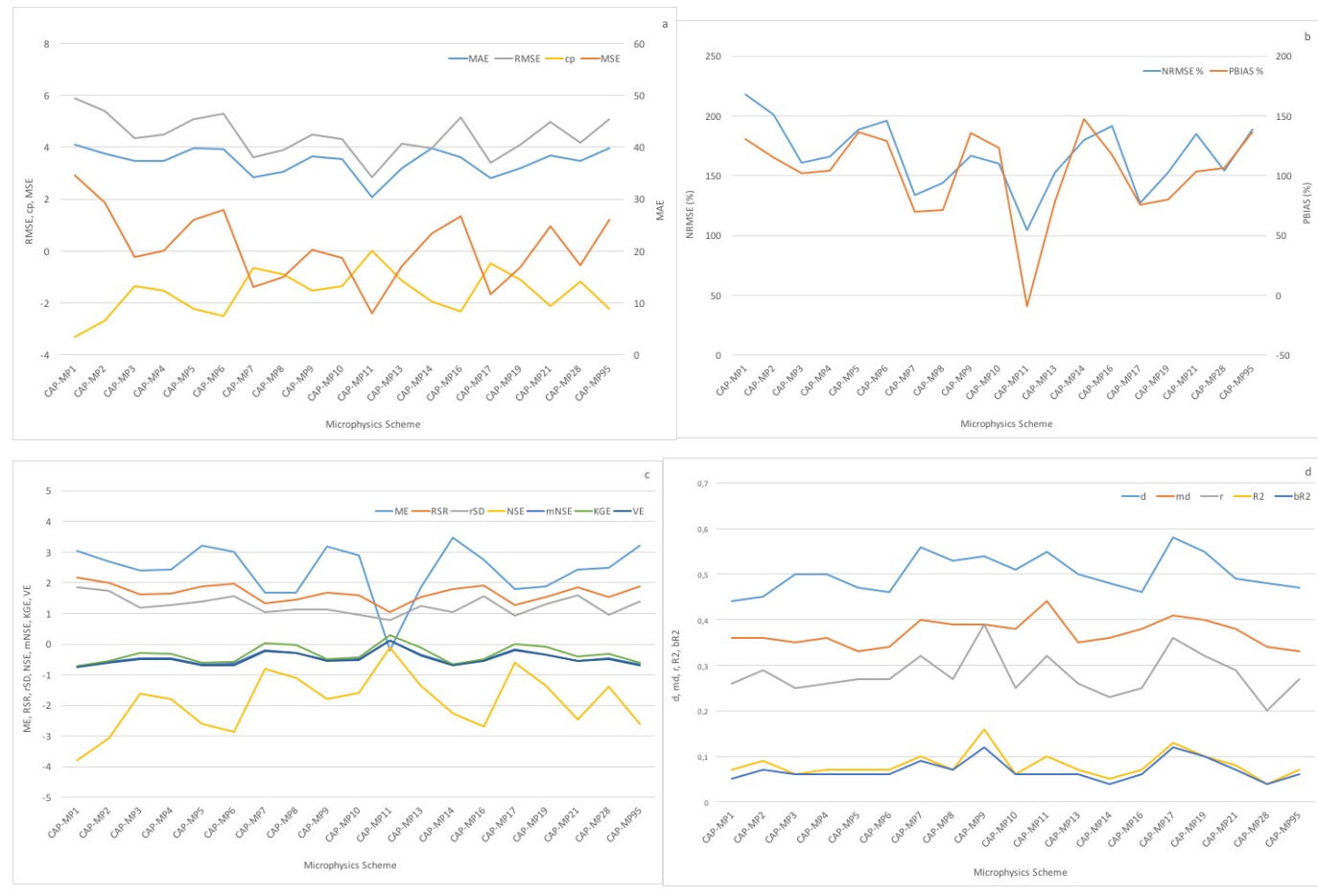

Figure 9. Microphysics Schemes versus errors at the CAPLES LAKE (CAP) station for each goodnees of fit test class (a. MAE, 5 RMSE, cp, MSE, b. NRMSE, PBIAS, c. ME, RSR, rSD, NSE, mNSE, KGE, VE, d. d, md, r, R2, bR2)

Because PBIAS values indicate both negative and positive values depending on the station, it may not be concluded that the WRF overestimates precipitation during hourly and point-wise evaluation, although Figures 4, 5, and 6 indicate this bias. However, an overestimation of light precipitation has

10 been detected in all of the MP scheme results, which is consistent with the findings of Gao and Sui (2013). 
Geosci. Model Dev. Discuss., doi:10.5194/gmd-2016-94, 2016

Manuscript under review for journal Geosci. Model Dev.

Published: 21 June 2016

(c) Author(s) 2016. CC-BY 3.0 License.

\subsection{2-hr total and basin-averaged comparisons}

The 72-hr basin averaged total precipitation of the WRF model is calculated by using the shape file of the American River Watershed borders, as presented in Figure 1 with green, following Tan (2010). Grid point rainfall values that are close to the ARW borderline are interpolated to the points of the border

5 shape file. Grid points that are located inside of the watershed are also included in the estimate of the hourly basin averaged values. The 72-hr total of these hourly values is compared to the adopted value of USACE (2005), which is $285 \mathrm{~mm}$ (shown in Figure X with a black line). In Figure 10, the 72-hr basinaveraged precipitation amount of each microphysics scheme is compared to the adopted value for the 72-hr time frame. Blue bars indicate that the basin averaged 72-hr total between December 31, 1996 and

10 January 3, 199700 PST (Pacific Standard Time) is consistent with the time frames of USACE (2005) and Tan (2010). MP1, MP2, MP3, MP4, and MP8 reach their 72-hr total maximum precipitation in this time interval. Green, yellow, and purple markers show that the 72 -hr total maximum precipitation is simulated with a 9-hr, 8-hr, and 6-hr time shift, respectively, according to the actual time frame. That is, MP9, MP10, and MP11 achieve maximum precipitation between December 30, 1996 15:00 PST and

15 January 2, 1997 15:00 PST (green markers in Figure 10), while the MP5, MP6, MP7, MP13, MP14, MP16, MP17, MP28, and MP95 schemes achieve total maximum precipitation between December 30, 1996 16:00 PST and January 2, 1997 16:00 PST (yellow markers in Figure 10). Similarly, MP19 and MP21 reach their maxima between December 30, 1996 18:00 PST and January 2, 1997 18:00 PST (purple markers in Figure 10). As also shown in Figure 10, the conclusion time of these intervals is

20 presented in the legends. True percent relative errors of the MP schemes (secondary ordinate in Figure 10) indicate that errors of 3 MPs are less than 5\%, i.e., MP7, MP8, and MP13. Moreover, MP8 might be counted as the best MP for the 72-hr basin averaged consideration because it is the only MP scheme that simulates the maximum precipitation at an accurate time interval among these 3 MPs. This result is consistent with the findings of Tan (2010), although she simulated the event using WRF V3.1.1, which

25 basically had $12 \mathrm{MP}$ schemes at that time. Her findings are also presented in Figure 10 (red markers) for comparison purposes. MP1, MP2, MP3, MP4, MP5, MP6, MP7, MP8, MP10, MP14, and MP16 can be compared with those of the current version (3.7.1). The red marker on MP28 indicates the result of the oldest Thompson scheme because the aerosol-aware Thompson scheme was not included in V3.1.1, as 
Geosci. Model Dev. Discuss., doi:10.5194/gmd-2016-94, 2016

Manuscript under review for journal Geosci. Model Dev.

Published: 21 June 2016

(c) Author(s) 2016. CC-BY 3.0 License.

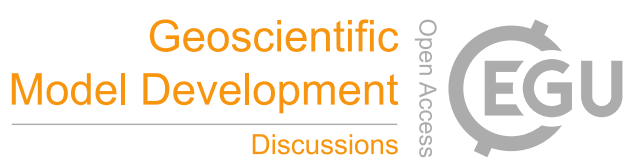

(c) (i)

in the case of schemes MP9, MP11, MP13, MP17, MP19, MP21, and MP95. Therefore, there is no red marker for them in the graph. Comparisons of the same microphysics schemes in different versions show that the precipitation amounts do also vary depending on the version of the model, although the same domains and same initial and boundary conditions are used. The general tendency is that V3.7.1

5 produces more precipitation than that of V3.1.1 for 9 MP schemes out of 11, where the 2 exceptions are MP2 and MP7.

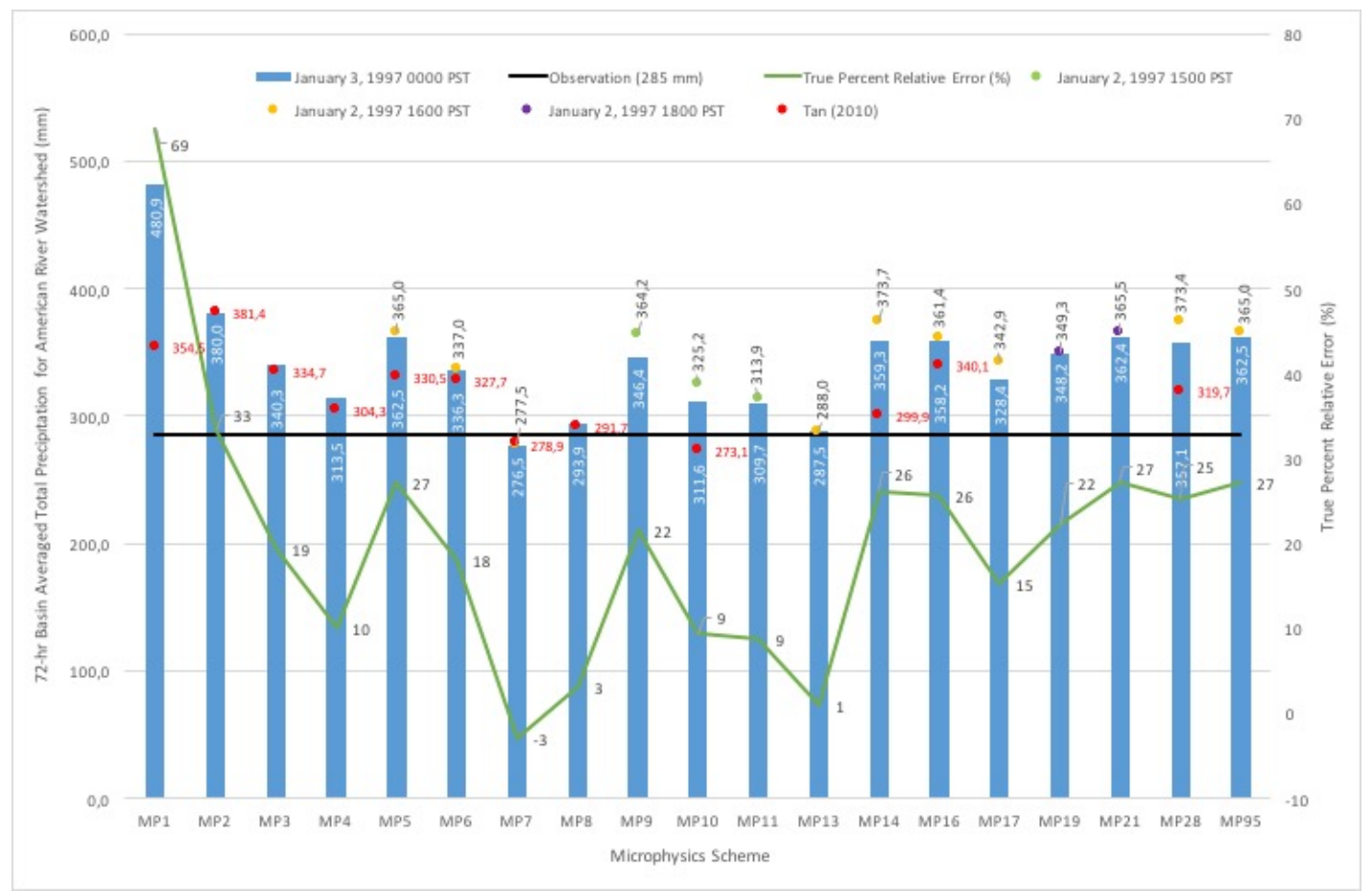

Figure 10. 72-hr basin-averaged total precipitation comparisons of microphysics schemes in terms of both precipitation amount and time.

Comparisons of Thompson schemes, which represent the best option among all, show that MP8 of the Thompson scheme in V3.1.1 (with $2.4 \%$ relative error (RE)) is slightly better than MP8 of the Thompson scheme in V3.7.1 (with 3.1\% RE). The oldest Thompson Scheme, MP98 in V3.1.1, has 
Geosci. Model Dev. Discuss., doi:10.5194/gmd-2016-94, 2016

Manuscript under review for journal Geosci. Model Dev.

Published: 21 June 2016

(c) Author(s) 2016. CC-BY 3.0 License.

12.2\% RE, whereas the newest Aerosol-Aware Thompson Scheme, MP28 in Version 3.7.1, has 25.3\%

RE. This might show us that the Aerosol-Aware Thompson scheme should be tested further to obtain better results for the maximum precipitation simulation of the American River Watershed.

V3.7.1 produces more precipitation than V3.1.1. Although domain setups are similar in these two

5 experiments, the only significant difference is the vertical level number. In this study, 41 vertical levels are utilized, whereas the study of Tan (2010) is based on 28 vertical levels. This might indicate that increasing vertical resolution adds spurious rainfall amount due to more frequent grid cell saturation. This result is consistent with the findings of Aligo et al. (2010), who also suggested that low vertical resolution in the initial and boundary conditions could be the reason for this counterintuitive finding.

\section{Summary and Conclusions}

In this paper, sensitivity experiments of 19 Microphysics (MP) schemes currently used in the WRF Model version 3.7.1, are performed to identify a model setup that minimizes the bias in hindcast simulations of the most impactful atmospheric river event, i.e., the 1997 New Year's storm. The

15 NCEP/NCAR Reanalysis data set is used for the initial and boundary conditions of the WRF Model. The hindcast simulation is constructed using 3 nested two-way domains, whose horizontal resolutions range from $27 \mathrm{~km}$ to $3 \mathrm{~km}$ with a ratio of 3, and the vertical resolution is determined using 41 sigma levels. 5-day simulations are conducted from December 29, 1996 at 06:00 UTC to January 3, 1997 at 06:00 UTC. The results of the innermost domain (3-km resolution) are presented, and their comparisons

20 with observations are discussed.

The 18 Goodness of Fit $(\mathrm{GoF})$ tests are utilized to evaluate the role of MP parameterization in terms of hourly and point-wise rainfall. One of the GoFs, i.e., cp, initially helps to decide which MP scheme's result are not comparable with observations. Applying the cp threshold, which is zero, several MP options are eliminated from further discussion. Out of 8 rain-gauge stations, only 3 of them (ALP, BTA,

25 and CAP) have comparable MP results. This might show that a significant source of error is still added to the model by means of MP schemes, depending on the location with consideration of hourly rainfall assessments. 
Geosci. Model Dev. Discuss., doi:10.5194/gmd-2016-94, 2016

Manuscript under review for journal Geosci. Model Dev.

Published: 21 June 2016

(c) Author(s) 2016. CC-BY 3.0 License.

Out of $18 \mathrm{GoFs}$, a combination of NRMSE and PBIAS metrics is utilized to determine the best MP option depending on the station location. According to these 2 metrics, MP3, MP8, MP17, and MP28 are the best options for the ALP station comparisons; MP3, MP8, MP9, and MP17 are the best for the BTA station; and MP11, as the only parameterization that passed, is the best for the CAP station 5 comparisons. The results do not indicate any systematic error for hourly and point-wise evaluations, and the errors of MP options vary depending on location and the amount of rainfall. However, overestimation of light precipitation has been detected in all of the MP scheme results, which is consistent with the findings of Gao and Sui (2013).

The 72-hr total and basin-averaged precipitation results of MPs indicate different behavior than that of

10 the hourly and point-wise comparisons. The results show that the 72-hr basin-averaged values are estimated much better than the hourly and point-wise calculations, as expected. However, the WRF's over-prediction bias is much more obvious than in the hourly comparisons. The most significant problem is to match the maximum precipitation in the observed time interval. Thus, the amount and the time interval are only estimated accurately by using the Thompson Scheme (MP8). This result is

15 consistent with the findings of Tan (2010), but the errors of her study are less than the findings of the current one because 41 vertical levels are used in this study, where as she used only 28 . It is assumed that this unexpected result is obtained as a result of either the low vertical resolution of the initial and boundary conditions or more frequent grid cell saturation calculation as the levels are increased (Aligo et al., 2010).

20 Another counterintuitive result is that the errors of MP8 are less than those of MP28. Because MP28 is an improved version of MP8 by means of adding the aerosol effect and Ault et al. (2011) mentioned that Asian dust may have an impact on atmospheric rivers, MP28 was expected to simulate more accurate precipitation values, at least for the 72-hr basin-averaged evaluations. Because MP28 works in two aerosol input modes, such as using constant values and using input from WPS, and the constant

25 value option is selected in this study, it is highly possible that the latter option may yield better results, which needs to be evaluated for the next studies with the actual aerosol distribution of the $1997 \mathrm{New}$ Year's storm. 
Geosci. Model Dev. Discuss., doi:10.5194/gmd-2016-94, 2016

Manuscript under review for journal Geosci. Model Dev.

Published: 21 June 2016

(c) Author(s) 2016. CC-BY 3.0 License.

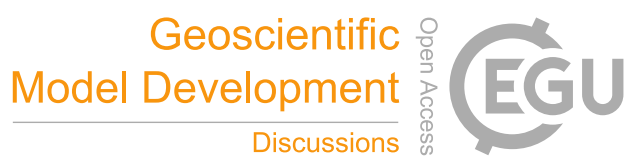

Regarding the ongoing debate, this study also shows that the WRF model results are better than these of the preceding one, i.e., MM5. For instance, Ohara et al. (2010) and Ishida et al. (2014) used MM5 to maximize precipitation to estimate Probable Maximum Precipitation (PMP) over the American River Watershed; and their constructed model results for the 1997 New Year's storm, with the 72-hr basin-

5 averaged perspective, were $330 \mathrm{~mm}$ and $325.54 \mathrm{~mm}$, which correspond to a $15.8 \%$ and $14.2 \%$ true percent relative error, respectively, based on the comparisons of this study. According to Tan (2010), who also simulated the 72-hr basin averaged precipitation using the WRF Model for the American River Watershed, this error is $2.4 \%$, whereas this study finds the relative error to be $3.1 \%$. Thus, this also shows us the importance of selecting the best MP options: if the calibrated models have larger 10 errors, then the simulations may also reserve them and indicate inaccurate results.

In conclusion, the results show us that the precipitation results of the WRF model can be used for design, water management and planning, and hindcasting purposes, with a high accuracy (less than 5\% $\mathrm{RE}$ ) when considering 72-hr basin-averaged values, whereas for the quantitative precipitation forecasting (QPF) purposes, which include hourly and point-wise evaluations, this accuracy varies

15 depending on the location and magnitude of the storm in addition to the choice of MP scheme. Because this study aims to evaluate mainly extreme precipitation, the BIAS test indicates a less than $10 \%$ accuracy range, whereas NRMSE shows that errors are greater than $90 \%$ for the best MP options. The results infer that precipitation simulations are highly sensitive to the MP choice, especially for extreme precipitation forecasting, as expected.

20 Model uncertainties in extreme precipitation simulations can also depend on the following factors, which are not discussed in this study:

- Horizontal resolution

- Domain selection

- Representative grid cell of the location

- Selection of other physical schemes rather than microphysics (MP)

- Initial and Boundary Condition data set

- Initial time setup of the event of interest

- Variety of events 
Geosci. Model Dev. Discuss., doi:10.5194/gmd-2016-94, 2016

Manuscript under review for journal Geosci. Model Dev.

Published: 21 June 2016

(c) Author(s) 2016. CC-BY 3.0 License.

- Evaluation of vertically integrated water vapor, i.e., Precipitable Water, simulations

- Detailed evaluation of physical processes in MP schemes.

In the future, these factors must be evaluated in detail to quantify the uncertainty of each component with respect to the intensity, duration, and the location of the extreme precipitation events.

\section{Code and data availability}

The Weather Research and Forecast Model (WRF) Advanced Research WRF (ARW) version 3.7.1 is evaluated in this paper. The code is freely available after a quick and free registration (http://www2.mmm.ucar.edu/wrf/users/download/get source.html). The WRF Model is initialized by using the 6-hour NCEP/NCAR Global Reanalysis Model (Kalnay et al., 1996), which can also be

10 downloaded after registration at the Research Data Archive (RDA) of the University Corporation for Atmospheric Research (UCAR) (NCEP et al., 1994) (http://rda.ucar.edu/datasets/ds090.0/). Hourly rain-gauge data are obtained from the California Data Exchange Center (CDEC) (http://cdec.water.ca.gov). Goodness-of-fit tests are performed by using R version 3.2.2 (2015-08-14) -"Fire Safety" Copyright (C) 2015 The R Foundation for Statistical Computing Platform: x86_64-apple-

15 darwin13.4.0 (64-bit) and the package hydroGOF is utilized accordingly (Mauricio, Z.-B.: hydroGOF: Goodness-of-fit functions for comparison of simulated and observed hydrological time series. $\mathrm{R}$ package version 0.3-8. http://CRAN.R-project.org/package=hydroGOF, 2014). The 72-hr total basin averaged precipitation value for the American River Basin is used, following the adopted value of the US Army Corps of Engineers (USACE, Stochastic modelling of extreme floods on the American River 20 at Folsom Dam, Appendix C 72-hour precipitation-frequency relationship and uncertainty analysis for the 1860-mi ${ }^{2}$ American River Watershed, RD-48C, US Army Corps of Engineers, Hydrological Engineering Center, 27pp, 2005) (http://www.hec.usace.army.mil/publications/ResearchDocuments/RD-48C.pdf). The 72-hr basinaveraged values of the WRF are extracted by using the shape file masking method of the NCAR 25 Command Language NCL (The NCAR Command Language (Version 6.3.0) [Software], Boulder, 
Geosci. Model Dev. Discuss., doi:10.5194/gmd-2016-94, 2016

Manuscript under review for journal Geosci. Model Dev.

Published: 21 June 2016

(c) Author(s) 2016. CC-BY 3.0 License.

Geoscientific
Model Development

Discussions

(c) (i)

Colorado: UCAR/NCAR/CISL/TDD, doi: 10.5065/D6WD3XH5, 2016).

(https://www.ncl.ucar.edu/Applications/shapefiles.shtml).

Finally, the $\mathrm{PhD}$ dissertation of Dr. Tan is available at

(https://www.researchgate.net/publication/252755552 Development of a methodology for probable

5 maximum precipitation estimation over the American River watershed using the WRF model)

DOI: 10.13140/RG.2.1.4069.4167.

Acknowledgements. I would like to thank Prof. M. Levent Kavvas for his mentorship during my $\mathrm{PhD}$ at UC Davis. Although the main focus of this manuscript is different from the subject of my $\mathrm{PhD}$

10 dissertation, I believe that the perception I gained from him helped me complete this work. Mr. Ali Hasan Tan for his valuable discussions regarding the methods and Ms. Burcu Yircali, for her help to edit the manuscript are kindly acknowledged.

I would also like to acknowledge the manuscript editing services provided by Nature Language Editing.

\section{References}

15 Aligo, E. A., William, A. G. Jr., and Segal, M.: On the Impact of WRF Model Vertical Grid Resolution on Midwest Summer Rainfall Forecasts. Weather and Forecasting, 24, 575-594, doi: 10.1175/2008WAF2007101.1, 2010.

Ault, A. P., Williams, C. R., White, A. B., Neiman, P. J., Creamean, J. M., Gaston, C. J., Ralph, F. M., and Prather, K. A.: Detection of Asian dust in California orographic precipitation, J. Geophys. Res., 116, D16205, doi:10.1029/2010JD015351, 2011.

Chai, T. and Draxler, R. R.: Root mean square error (RMSE) or mean absolute error (MAE)? Arguments against avoiding RMSE in the literature, Geosci. Model Dev., 7, 1247-1250, doi:10.5194/gmd-7-1247-2014, 2014.

Dettinger, M.: Climate Change, Atmospheric Rivers, and Floods in California - A Multimodel Analysis of Storm Frequency and Magnitude Changes, Journal of the American Water Resources Association (JAWRA), 47, 3, 514-523. doi: 10.1111/j.1752-1688.2011.00546.x, 2011. 
Geosci. Model Dev. Discuss., doi:10.5194/gmd-2016-94, 2016

Manuscript under review for journal Geosci. Model Dev.

Published: 21 June 2016

(c) Author(s) 2016. CC-BY 3.0 License.

Eaton, B.: User's Guide to the Community Atmosphere Model CAM-5.1., NCAR. URL http://www.cesm.ucar.edu/models/cesm1.0/cam, 2011.

Eiserloh, A. J. Jr. and Chiao, S.: Modeling studies of landfalling atmospheric rivers and orographic precipitation over northern California, Meteorol Atmos Phys, 127, 1, 1-16, doi: 10.1007/s00703-0140350-4, 2014.

Ferrier, B. S., Tao, W.-K., and Simpson, J.: A double-moment multiple-phase four-class bulk ice scheme. Part II: Simulations of convective storms in different large-scale environments and comparisons with other bulk parameterizations, Journal of the atmospheric sciences, 52, 8, 10011033, doi: 10.1175/1520-0469(1995)052<1001:ADMMPF>2.0.CO;2, 1995.

10 Gao, W. and Sui, C-H.: A modeling analysis of rainfall and water cycle by the cloud-resolving WRF model over the western North Pacific, Adv. in Atm. Sci., Volume 30, Issue 6, pp 1695-1711, doi: 10.1007/s00376-013-2288-8, 2013.

Gilmore, M. S., Straka, J. M., and Rasmussen, E. N.: Precipitation uncertainty due to variations in precipitation particle parameters within a simple microphysics scheme, Mon. Wea. Rev., 132, 26102627, doi: 10.1175/MWR2810.1, 2004.

Gómez-Navarro, J. J., Raible, C. C., and Dierer, S.: Sensitivity of the WRF model to PBL parametrisations and nesting techniques: evaluation of wind storms over complex terrain, Geosci. Model Dev., 8, 10, 3349-3363, doi:10.5194/gmd-8-3349-2015, 2015.

Han, M., Braun, S. A., Matsui, T., and Williams, C. R.: Evaluation of cloud microphysics schemes in simulations of a winter storm using radar and radiometer measurements, J. Geophys. Res. Atmos., 118, 1401-1419, doi:10.1002/jgrd.50115, 2013.

Hong, S-Y, Dudhia, J., and Chen, S-H: A revised approach to ice microphysical processes for the bulk parameterization of clouds and precipitation, Mon. Wea. Rev., 132, 103-120, doi: 10.1175/15200493(2004)132<0103:ARATIM>2.0.CO;2, 2004.

25 Hong, S.-Y., and Lim, J.-O. J.: The WRF single-moment 6-class microphysics scheme (WSM6). J. Korean Meteor. Soc., 42, 129-151, 2006.

Houze, R. A. Jr.: Orographic effects on precipitating clouds, Rev. Geophys., 50, RG1001, doi:10.1029/2011RG000365, 2012. 
Geosci. Model Dev. Discuss., doi:10.5194/gmd-2016-94, 2016

Manuscript under review for journal Geosci. Model Dev.

Published: 21 June 2016

(c) Author(s) 2016. CC-BY 3.0 License.

Hu, X-M., Nielsen-Gammon, J. W., and Zhang, F.: Evaluation of Three Planetary Boundary Layer Schemes in the WRF Model, J. Appl. Meteor. Climatol., 49, 1831-1844, doi: 10.1175/2010JAMC2432.1, 2010.

IPCC: Summary for Policymakers. In: Managing the Risks of Extreme Events and Disasters to Advance

Climate Change Adaptation [Field, C.B., V. Barros, T.F. Stocker, D. Qin, D.J. Dokken, K.L. Ebi, M.D. Mastrandrea, K.J. Mach, G.-K. Plattner, S.K. Allen, M. Tignor, and P.M. Midgley (eds.)]. A Special Report of Working Groups I and II of the Intergovernmental Panel on Climate Change. Cambridge University Press, Cambridge, UK, and New York, NY, USA, pp. 1-19, 2012.

Jankov, I., Schultz, P. J., Anderson, C. J., and Koch, S. E.: The Impact of Different Physical Parameterizations and Their Interactions on Cold Season QPF in the American River Basin. J. Hydrometeor, 8, 1141-1151, doi: 10.1175/JHM630.1, 2007.

Jankov, I., Bao, J-W., Neiman, P. J., Schultz, P. J., Yuan, H., and White, A. B.: Evaluation and Comparison of Microphysical Algorithms in ARW-WRF Model Simulations of Atmospheric River Events Affecting the California Coast. J. Hydrometeor, 10, 847-870, doi: 10.1175/2009JHM1059.1, 2009.

Jankov, I., Grasso, L. D., Sengupta, M., Neiman, P. J., Zupanski, D., Zupanski, M., Lindsey, D., Hillger, D. W., Birkenheuer, D. L., Brummer, R., and Yuan, H.: An Evaluation of Five ARW-WRF Microphysics Schemes Using Synthetic GOES Imagery for an Atmospheric River Event Affecting the California Coast, Journal of Hydrometeorology, 12, 4, 618-633, doi: 10.1175/2010JHM1282.1, 2011.

Kalnay et al: The NCEP/NCAR 40-year reanalysis project. Bulletin of the American Meteorological Society, 77, 3, 437-471, doi: 10.1175/1520-0477(1996)077<0437:TNYRP>2.0.CO;2, 1996.

Kessler, E.: On the continuity and distribution of water substance in atmospheric circulations, Atm. Res., 38, Issues 1-4, 109-145. doi:10.1016/0169-8095(94)00090-Z, 1995.

25 Khain, A., Pokrovsky, A., Pinsky, M., Seifert, A., and Phillips, V.: Simulation of effects of atmospheric aerosols on deep turbulent convective clouds using a spectral microphysics mixed-phase cumulus cloud model. Part I: model description and possible applications. J. Atmos. Sci., 61, 2963-2982, doi: 10.1175/JAS-3350.1, 2004. 
Geosci. Model Dev. Discuss., doi:10.5194/gmd-2016-94, 2016

Manuscript under review for journal Geosci. Model Dev.

Published: 21 June 2016

(c) Author(s) 2016. CC-BY 3.0 License.

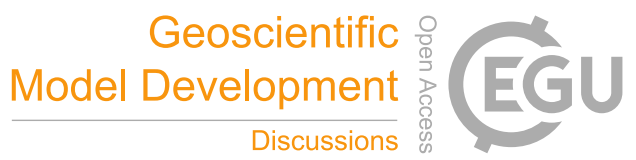

Khain, A., Lynn, B., and Dudhia, J.: Aerosol effects on intensity of landfalling hurricanes as seen from simulations with the WRF model with spectral bin microphysics, J. Atmos. Sci., 67, 365-384, doi: 10.1175/2009JAS3210.1, 2010.

Lim, K.-S. S., and Hong, S.-Y.: Development of an effective double-moment cloud microphysics 5 scheme with prognostic cloud condensation nuclei $(\mathrm{CCN})$ for weather and climate models. Mon. Wea. Rev., 138, 1587-1612, doi: 10.1175/2009MWR2968.1, 2010.

Lin, Y., and Colle, B. A.: A new bulk microphysical scheme that includes riming intensity and temperature-dependent ice characteristics. Mon. Wea. Rev., 139, 1013-1035, doi: 10.1175/2010MWR3293.1, 2011.

10 Lin, Y-L, Farley, R. D., and Orville, H. D.: Bulk Parameterization of the Snow Field in a Cloud Model. J. Climate Appl. Met., 22, 1065-1092, doi: 10.1175/1520-0450(1983)022<1065:BPOTSF >2.0.CO;2, 1983.

Mansell, E. R., Ziegler, C. L., and Bruning, E. C.: Simulated electrification of a small thunderstorm with two-moment bulk microphysics, J. Atmos. Sci., 67, 171-194, doi: 10.1175/2009JAS2965.1, 152010.

Mauricio, Z.-B.: hydroGOF: Goodness-of-fit functions for comparison of simulated and observed hydrological time series. R package version 0.3-8. http://CRAN.R-project.org/package=hydroGOF, 2014.

Milbrandt, J. A. and Yau, M. K.: A multimoment bulk microphysics parameterization. Part I: Analysis of the role of the spectral shape parameter. J. Atmos. Sci., 62, 3051-3064, doi: 10.1175/JAS3534.1, 2005a.

Milbrandt, J. A. and Yau, M. K.: A multimoment bulk microphysics parameterization. Part II: A proposed three-moment closure and scheme description. J. Atmos. Sci., 62, 3065-3081, doi: 10.1175/JAS3535.1, 2005b.

25 Morrison, H., Thompson, G., and Tatarskii, V.: Impact of Cloud Microphysics on the Development of Trailing Stratiform Precipitation in a Simulated Squall Line: Comparison of One- and Two-Moment Schemes. Mon. Wea. Rev., 137, 991-1007, doi: 10.1175/2008MWR2556.1, 2009. 
Geosci. Model Dev. Discuss., doi:10.5194/gmd-2016-94, 2016

Manuscript under review for journal Geosci. Model Dev.

Published: 21 June 2016

(c) Author(s) 2016. CC-BY 3.0 License.

NCEP et al.- National Centers for Environmental Prediction/National Weather Service/NOAA/U.S. Department of Commerce: NCEP/NCAR Global Reanalysis Products, 1948-continuing. Research Data Archive at the National Center for Atmospheric Research, Computational and Information Systems Laboratory. http://rda.ucar.edu/datasets/ds090.0/, 1994, Accessed 21 Feb 2016.

5 NCL, The NCAR Command Language (Version 6.3.0) [Software], Boulder, Colorado: UCAR/NCAR/CISL/TDD, doi: 10.5065/D6WD3XH5, 2016.

NOAA, cited 2001: National Oceanic and Atmospheric Administration Changes to the NCEP Meso Eta Analysis and Forecast System: Increase in resolution, new cloud microphysics, modified precipitation assimilation, modified analysis. http://www.emc.ncep.noaa.gov/mmb/mmbpll/eta12tpb/

Ralph, F. M., Neiman, P. J., and Wick, G. A.: Satellite and CALJET aircraft observations of atmospheric rivers over the North Pacific Ocean during the winter of 1997/98. Mon. Wea. Rev., 132, 1721-1745, doi: 10.1175/1520-0493(2004)132<1721:SACAOO>2.0.CO;2, 2004.

Reisner, J., Rasmussen, R. M., and Bruintjes, R. T.: Explicit forecasting of supercooled liquid water in winter storms using the MM5 mesoscale model, Quarterly Journal of the Royal Meteorological Society, 124, 548, 1071-1107, doi: 10.1002/qj.49712454804, 1998.

Rutledge, S. A., and Hobbs, P. V.: The Mesoscale and Microscale Structure and Organization of Clouds and Precipitation in Midlatitude Cyclones. XII: A Diagnostic Modeling Study of Precipitation Development in Narrow Cold-Frontal Rainbands, J. Atmos. Sci., 41, 2949-2972, doi: 10.1175/15200469(1984)041<2949:TMAMSA>2.0.CO;2, 1984.

Skamarock, W. C., Klemp, J. B., Dudhia, J., Gill, D. O., Barker, D. M., Duda M. G., Huang X., Wang W., and Powers, J. G.: A description of the Advanced Research WRF Version 3. NCAR Tech. Note, NCAR/TN-475+STR, 125 pp., 2008.

Tan, E.: Development of a Methodology for Probable Maximum Precipitation Estimation Over the 25 American River Watershed Using the WRF Model, Partially Published PhD. Dissertation, Department of Civil and Environmental Engineering, University of California, Davis, 175 pp., 2010.

Tao, W.-K., Simpson, J., and McCumber, M.: An Ice-Water Saturation Adjustment, Mon. Wea. Rev., 117, 231-235, doi: 10.1175/1520-0493(1989)117<0231:AIWSA>2.0.CO;2, 1989. 
Geosci. Model Dev. Discuss., doi:10.5194/gmd-2016-94, 2016

Manuscript under review for journal Geosci. Model Dev.

Published: 21 June 2016

(c) Author(s) 2016. CC-BY 3.0 License.

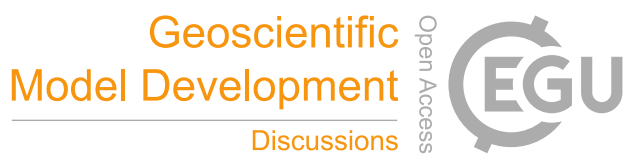

Thompson, G., Field, P. R. Rasmussen, R. M., and Hall, W. D.: Explicit Forecasts of Winter Precipitation Using an Improved Bulk Microphysics Scheme. Part II: Implementation of a New Snow Parameterization. Mon. Wea. Rev., 136, 5095-5115, doi: 10.1175/2008MWR2387.1, 2008.

Thompson, G., and Eidhammer, T.: A study of aerosol impacts on clouds and precipitation development in a large winter cyclone. J. Atmos. Sci., 71, 10, 3636-3658, doi: 10.1175/JAS-D-13-0305.1, 2014.

URL-1: http://www.wrcc.dri.edu/extremeevents/california/\#1997\%20New\%20Year's\%20Flood

URL-2, California Data Exchange Center (CDEC), http://cdec.water.ca.gov

USACE, Stochastic modelling of extreme floods on the American River at Folsom Dam, Appendix C72-hour precipitation-frequency relationship and uncertainty analysis for the $1860-\mathrm{mi}^{2}$ American 10 River Watershed, RD-48C, US Army Corps of Engineers, Hydrological Engineering Center, 27pp, 2005.

Zhu, Y. and Newell, R. E.: A proposed algorithm for moisture fluxes from atmospheric rivers. Mon Wea Rev, 126, 725-735, doi: 10.1175/1520-0493(1998)126<0725:APAFMF>2.0.CO;2, 1998.

Ziegler, C. L.: Retrieval of thermal and microphysical variables in observed convective storms. Part 1 : 15 Model development and preliminary testing, Journal of the atmospheric sciences, 42, 14, 1487-1509, doi: 10.1175/1520-0469(1985)042<1487:ROTAMV>2.0.CO;2, 1985. 